\title{
Developing English Materials for Front Office for XI Grade Students at SMK N 2 Singaraja
}

\author{
Ketut Puspa Dewi ${ }^{1}$ \\ Universitas Pendidikan Ganesha, Indonesia \\ ketutpuspadewi93@gmail.com \\ Nyoman Karina Wedhanti ${ }^{2}$ \\ Universitas Pendidikan Ganesha, Indonesia \\ karina.wedhanti@undiksha.ac.id \\ Kadek Sintya Dewi ${ }^{3}$ \\ Universitas Pendidikan Ganesha, Indonesia \\ sintya09@yahoo.com \\ I Gede Budasi ${ }^{4}$ \\ gede.budasi@undiksha.ac.id
}

\begin{abstract}
The aim of this study is to develop materials for English for front office use by the $\mathrm{XI}$ grade students in first semester at SMK N 2 Singaraja. This study is to develop as supplementary materials based on the student's need analysis using the theory suggested by Hutchinson and Waters (1987). The subjects of this research included one the front office teacher, 40 students of the school and one of the front office staff who worked at Dash Hotel in Seminyak, Bali. Design and development method (D\&D) by Richey \& Klein (2017) were applied in this study. A questionnaires and a checklist were used as the instruments in collecting the obtained data of the study. Three steps which include: 1) Design (Conducting Needs Analysis), 2) Develop (Developing the Product), and 3) Evaluation (Judging the quality of the product) were past in in the materials development. The findings of this study show that there were 5 topics needed to be developed which include: (1) Handling incoming calls (2) Handling of telephone calls (3) Reservation process (4) Handling individual reservations (5) Handling group reservations to be develop. Each of which will be developed into a units which consist of input, content focus, language focus, and task. The design materials was categories as a very high validity, therefore it is suggested to be used as the supplementary materials for the school.
\end{abstract}

Keywords: English Learning Materials, ESP, English for Front office, Need Analysis

\section{INTRODUCTION}

Bali is one of the islands that have many tourism attractions. Having a beautiful view is one of the characteristics of Bali. Taman Ujung, Lake Batur, Kuta Beach, and Gitgit Waterfall are some of the tourism object that are often visited during holidays by domestic and foreign guests. According to the 
Provincial Statistics Center of Bali (Badan Pusat Statistik Provinsi Bali), the Countries that frequently visit Bali are China (21.09\%), Australia $(19.49 \%)$, India $(5.63 \%)$, Russia (4.82\%), South Korea (4 , 45\%), the United States $(3.86 \%)$, Britain (3.51\%), Japan (3.23\%), Malaysia (2.77\%), and Singapore (2.16\%). From above data, it can be concluded that Bali is a favourite destination for vacationers in various countries. If many foreigners come to Bali, it could increase the income of the Balinese people, by selling things such accessories, clothes, or crafts. In addition local people can also get jobs, because many of them spend their time in Bali for a long day so they will stay at the hotel. According to Carev, Danijel (2015) the hotel is defined as commercially managed building by providing public lodging and service facilities such as food and beverage services, room service, luggage service, laundry, etc. The hotel is closely related to the tourism industry. It has an important role in supporting the development of the tourism industry, because when guests want to do vacation in Bali for a long time, they will stay at the hotels which have complete facilities and service that greatly affect the comfort of the guest. One of hotel department that greet the guess for the first time is front office department.

Front Office (FO) is one of the departments of a hotel that is firstly encounter by the guest arriving at the hotel. According to Bhakta, Anutosh (2012), FO department is responsible for the sale of hotel rooms either to guests who arrive directly (walk in) or guests with room bookings (with reservation). The images of the hotel are good or not can be felt by guests when they know the services of front office staff for the first time, because the front office as the face of the hotel. According to Wood, Roy C.Kooi, Simen (2017) the comfort of guests from their arrive, during stay, and when leaving the hotel is the responsibility of $t$, especially those who work in FO department, because all information relating to the hotel area is the responsibility of the FO department. Therefore, it is important for hotel staff to know about the hotel, and can communicate with guests to convey all information about the hotel using good English. Thus, human resources, especially students who study the front office at schools must be prepared them self. The preparation included starting from the materials that they learned at the school should be related to the action in the tourism sector, especially to master English as the language of international communication.

According to Zahedpisheh, et al (2017), English is the language which is widely used in the international tourism in the twenty-first century. This is because English has become the language of international communication between countries. Studying English for more specific things, like English for tourism, is called ESP. According to Hutchinson and Waters (1987, p. 19) as cited in Oktaviyanti \& Fatmasari (2018) state ESP is an approach to language learning which is based on the learner's need in the future. By preparing the concept of ESP, it can help students prepare well for the future to meet their workplace requirements in the future. For addition, according to Chang, 2009; Tsao, 2011 as cited by Zahedpisheh, et al (2017), ESP is recommended to apply to the learners who are required to achieve their specific and precise needs or goals in the future. When students work in the front office department, students will use English to communicate with guests, for example when serving guests check in, check out, etc. Therefore, the material needed by students that adjust to what students need in the FO field, it call as students' need analysis. 
However, there are many tourism schools in Bali, especially in Singaraja that have not been able to prepare a complete textbook to discuss activities in the front office lesson. One of them is at SMK N 2 Singaraja in XI grade students in hotel accommodation program. Based on the observation of the textbook and through the Google form, the researcher was found that the problems are: the textbook needs more illustration and variations of assignment to make students more practice. Even if students want to become a good FO staff in the future, students must have authentic materials that present lot activities in front office field as basic knowledge and also their book need to use English, because when they work in FO department, they will use English to communicate with the guest.

Those problems above guided the researcher to develop FO materials for $\mathrm{XI}$ grade students of the hotel accommodation program need to do to make a renewed material. This prospective textbook will design with title "Supplementary Material English for Front Office ". Based on observations, checklist, and analysis of the syllabus and the textbook, this material was developed and consisted of 9 units for two semesters (semester $1 \& 2$ ) in XI grade, which are (1) Handling Incoming calls (2) Handling of telephone calls (3) Reservation process (4) Handling individual reservations (5) Handling group reservations (6) renewal of reservations (7) Cancellation of reservations, (8) Handling of group reservations orally and in writing, and (9) Handling of individual reservations orally and in writing. Unit 1-5 is for semester one, and unit 6-9 is for semester two. The focus of this research is to compiling the book in units 1-5 (semester 1), because other material will develop by other researcher. The purpose of this research is to Develop English material for front office for XI grade students in first semester at SMK N 2 Singaraja. This prospective textbook will be developed in two ways which are online (e-book) and offline (printed). The reason of researcher develop online book (e-book) is because we are still in pandemic of Covid-19, as we know all of learning process done in online. It will help students to read this book everywhere and anytime, they just need to save it on their smart phone.

According to Tomlinson (2008) as cited in Sri Rahayu and Budasi (2021), material development refers to whatever is done by the writer, teacher or learner to provide sources of language input and to exploit these sources to supply information about language in ways designed to promote language learning. In addition Tomlinson explain the development of material is everything that is made by people (writers, teachers, or students) to provide information and provide experience using language, which is designed to obtain language learning. In connection with that statement, Tomlinson (2011) states the material for language learning is agreed on matters that help students to learn language. Materials include books, videos, multi-level readers, flash cards, games, websites, and mobile interactions, as if inevitable, and much literature on printed material.

There are several criteria to develop learning materials that appropriate for students. According to Moore, 1977; Hutchington \& Water, (1987) as cited in Oktaviyanti \& Fatmasari (2018) the material must consider six characteristics, which are, First the material must have a clear purpose, the second type of exercise that gives students the opportunity to use language, thirdly the content, the material must have clear instructions so that it is easily understood by 
students, fourth interest, the material must be able to make students interested in learning for example by how to add multiple images related to the material. Fifth authentically, the material is relevant to the work life of students in the future. Last is difficulty, the material must also pay attention to the level of difficulty in accordance with the level of students. Therefore, it is important for students to have a book or teaching material that is relevant to the material criteria that have been submitted previously.

There are 4 important aspects would be included in the developed materials in each units, namely : input, content focus, language focus, and tasks (Hutchinson \& Waters, 1987) as cited in Sri Rahayu and Budasi (2021). Input in the book will include short dialogs or pictures that serve the activity of FO staff in the hotel. The second content focus is the material that must be understood by students who will be the core of the discussion of the unit. Third, language focus, which discusses language patterns in the form of grammar reviews, vocabulary use complete with how to pronounce it. This language focus is expected to help students more easily understand the grammar, and enrich the vocabulary. And the last is tasks, in this section will present about the various tasks that students must do in order to check their understanding of the material. In addition, providing various problem exercises will help students to master what students expect. The task consists of fourth language skills namely listening, speaking, reading, and writing in each unit related to front office activities. The purpose of this study are to: (1) develop English materials for FO for XI grade students in first semester at SMKN 2 Singaraja, (2) describe how the materials develop, and (3) describe the quality of the product.

Based on those previous studies, we know that a study on the front office field has been carried out by many researchers using different methods and different instruments. The difference between the present study and the previous study was that the previous study mostly discussed front office material for the college students, but in this study it will develop the material in one of the vocational high schools in Singaraja. However, in this study only developed material for class $\mathrm{XI}$ in the first semester. Then the product stage of present research (textbook) will only be completed until the evaluation carried out by an expert judge without implementing it to schools for reasons of limited time and a pandemic that makes it impossible to implement it.

\section{METHOD}

This research design adopted theory from Richey and Klein (2017) as cited in Ariyanthi, Ketut Eni Putra, I Nyoman Adi Jaya Suarcaya, Putu which is Design and Development (D\&D) method. This study is to develop a book based on the students' need. This research method consists of three processes are design, develop, and evaluate. 
The Art of Teaching English as a Foreign Language, Vol.2 No.1 2021

p-ISSN : 2656-8942, e-ISSN : 2684-8546

DOI: $10.36663 /$ tatefl.v2i1.99

Figure.1 Richey \& Klein Model

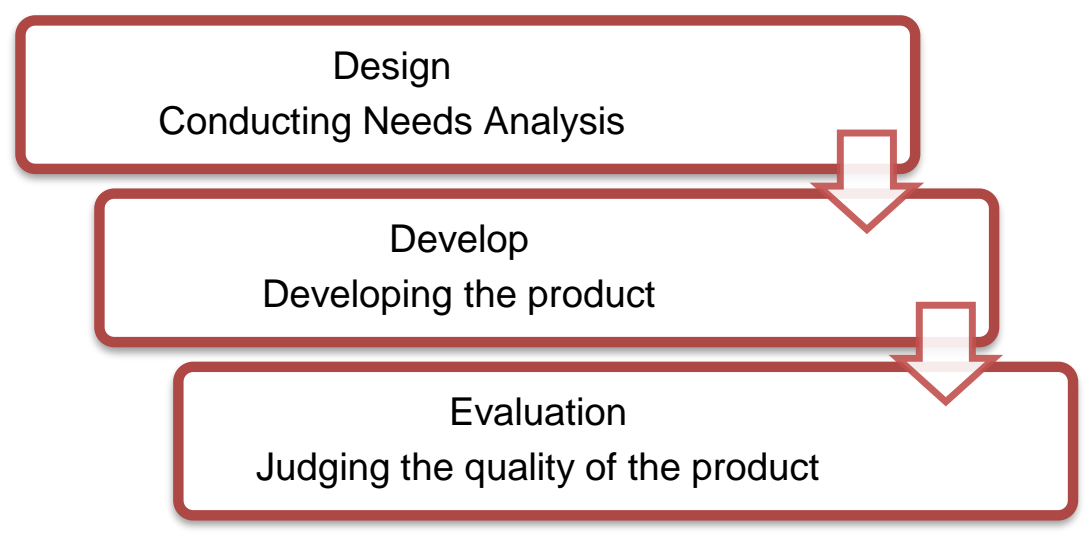

In design process, there are three steps done by researcher namely; classroom observation, document analysis (textbook \& syllabus analysis), and needs analysis. In develop process the researcher develop the product (textbook and e-book). In developing this product, the researcher applied 4 important aspects that would be present in each unit adopted from Hutchingson \& Waters (1987) as cited in Sri Rahayu and Budasi (2021), namely Input, Language focus, Content focus, and Task. The last step is evaluation, in which in this step the researcher evaluated the product quality. This evaluation has done by 2 expert judges who expert in ESP field. The evaluation in form of checklist included a good material adopted from Litz.

The subjects of this study were the Front office teachers of $\mathrm{XI}$ grade students at SMK Negeri 2 Singaraja, students in XI grade (XI AP 4) which consist of 40 students, and hotel staff who worked in Front Office department. The object of this study is Front office materials developed as the learning media. The research instruments used in this study to collect the data were questionnaires and checklist. The steps of the interactive data analysis method adopted from Miles and Huberman (1994) consist of data reduction, data display, and drawing the conclusion.

There are two kind of instrument were used namely need analysis questionnaire, and check list. In this study the researchers use need analysis questionnaire in order to know students' need. Then, checklist given to students is used to know the percentages of their need about the topic. Other checklist is used for expert judges to evaluate the product. The checklist is adapted theory from Litz.

\section{FINDINGS AND DISCUSSIONS}

This part discusses about the results of the research in order to answer the research questions. There are 3 research questions of this study, that is, (1). What materials are needed to be developed in SMK N 2 Singaraja for XI grade students in first semester?, (2) How the materials were develop?, and (3) What is the quality of the product?

\section{Developing materials based on student's need analysis}

a. The result of students' checklist 
Based on the result of students' checklist, the learning material needed to be developed for XI grade students in first semester of SMK N 2 Singaraja consisted of 5 topics. The 5 units existed in the developed book are as follows:

1) Handling incoming calls. The learning objectives should achieve by the students in the material are students are able to identify the meaning of telephone operator, students are able to demonstrate how to handling incoming call based on standard operational procedure.

2) Handling of telephone calls. The learning objectives should achieve by the students in the material is students are able to interpret how to making a call in a correct way

3) Reservation process. The learning objectives should achieve by the students in the material is students are able to identify the meaning and categories of reservation process.

4) Handling individual reservations. The learning objectives should achieve by the students in the material is students are able to handling individual reservation based on standard operational procedure.

5) Handling group reservations. The learning objectives should achieve by the students in the material is students are able to handling group reservation based on standard operational procedure.

Above units know based on the result of the percentage from the students' checklist. To determine the percentage of checklist results can be formulated as follows:

Number of students who answered "need" X $100 \%$

Total number of students

The percentage can be seen in the following table.

Table 1. The Result of Students' Checklist

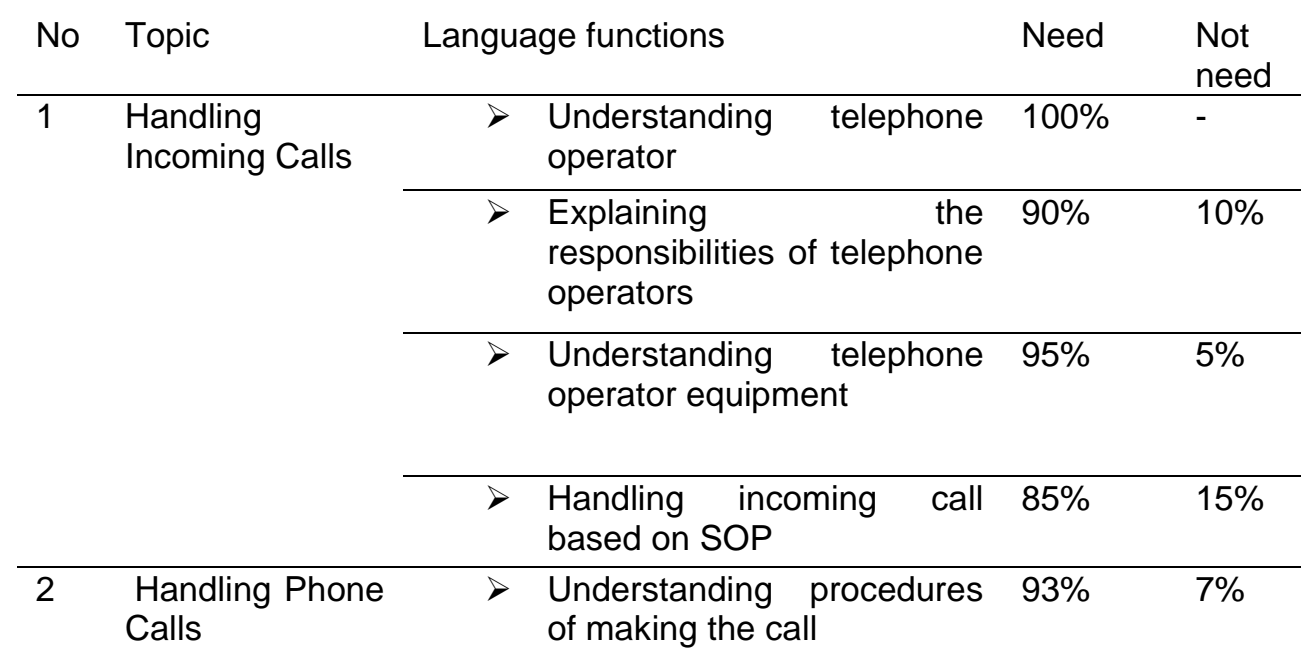


The Art of Teaching English as a Foreign Language, Vol.2 No.1 2021

p-ISSN : 2656-8942, e-ISSN : 2684-8546

DOI: $10.36663 /$ tatefl.v2i1.99

\begin{tabular}{|c|c|c|c|c|c|}
\hline & & $>$ & $\begin{array}{l}\text { Determining phone call } \\
\text { preparation }\end{array}$ & $98 \%$ & $2 \%$ \\
\hline & & $>$ & Obstacles in making the call & $93 \%$ & $7 \%$ \\
\hline & & $>$ & $\begin{array}{l}\text { Preparing the tools before } \\
\text { making the call }\end{array}$ & $100 \%$ & - \\
\hline 3 & $\begin{array}{l}\text { Reservation } \\
\text { Process }\end{array}$ & $>$ & $\begin{array}{l}\text { Understanding the } \\
\text { reservation process and } \\
\text { categories of reservation }\end{array}$ & $95 \%$ & $5 \%$ \\
\hline & & $>$ & $\begin{array}{lr}\text { Understanding } & \text { the } \\
\text { responsibilities } & \text { of } \\
\text { reservation process } & \end{array}$ & $98 \%$ & $2 \%$ \\
\hline & & $>$ & $\begin{array}{l}\text { Understanding the source of } \\
\text { reservation }\end{array}$ & $98 \%$ & $2 \%$ \\
\hline & & $>$ & $\begin{array}{l}\text { Explaining the conventional } \\
\text { chart, density chart, dan } \\
\text { stop go chart }\end{array}$ & $95 \%$ & $5 \%$ \\
\hline & & $>$ & $\begin{array}{l}\text { Explaining the tools of } \\
\text { reservation }\end{array}$ & $90 \%$ & $10 \%$ \\
\hline & & $>$ & $\begin{array}{l}\text { Explaining the types of } \\
\text { reservation }\end{array}$ & $93 \%$ & $7 \%$ \\
\hline & & $>$ & $\begin{array}{l}\text { Explaining the procedures } \\
\text { of reservation process }\end{array}$ & $93 \%$ & $7 \%$ \\
\hline & & $>$ & $\begin{array}{l}\text { Handling } \\
\text { process }\end{array}$ & $98 \%$ & $2 \%$ \\
\hline 4 & $\begin{array}{l}\text { Handling } \\
\text { individual }\end{array}$ & $>$ & $\begin{array}{l}\text { Explaining } \\
\text { reservation }\end{array}$ & $98 \%$ & $2 \%$ \\
\hline & reservation & $>$ & $\begin{array}{l}\text { Explaining the process } \\
\text { handling group reservation }\end{array}$ & $88 \%$ & $12 \%$ \\
\hline & & $>$ & $\begin{array}{l}\begin{array}{l}\text { Explaining the tools for } \\
\text { handling } \\
\text { reservation }\end{array} \\
\text { individual }\end{array}$ & $85 \%$ & $15 \%$ \\
\hline & & $>$ & $\begin{array}{l}\text { Handling individual } \\
\text { reservation based on SOP }\end{array}$ & $93 \%$ & $7 \%$ \\
\hline 5 & $\begin{array}{l}\text { Handling group } \\
\text { reservation }\end{array}$ & $>$ & $\begin{array}{l}\text { Explaining } \\
\text { reservation }\end{array}$ & $93 \%$ & $7 \%$ \\
\hline
\end{tabular}


The Art of Teaching English as a Foreign Language, Vol.2 No.1 2021

p-ISSN : 2656-8942, e-ISSN : 2684-8546

DOI: $10.36663 /$ tatefl.v2i1.99

\begin{tabular}{llll}
\hline & $\begin{array}{l}\text { Explaining the process } \\
\text { handling group reservation }\end{array}$ & $93 \%$ & $7 \%$ \\
\hline $\begin{array}{l}\text { Explaining the tools for } \\
\text { handling } \\
\text { reservation } \\
\text { individual }\end{array}$ & $88 \%$ & $12 \%$ \\
\hline $\begin{array}{l}\text { Handling individual } \\
\text { reservation based on SOP }\end{array}$ & & \\
\hline & $98 \%$ & $12 \%$ \\
\hline
\end{tabular}

The result of students' responses above show that most of students agreed with the statements of the checklist with the average obtained for the need response was $92.8 \%$ and $6.6 \%$ for not need response.

b. The result of students', teacher, and front office staff questionnaire.

The researcher share the questionnaire through Google form to students in order to know the content of material included in the product. The parts of questions of this questionnaire are: (1) Are you interested in a book with lots of conversations?, (2) Are you interested in a book with pictures?, (3) Are you interested in books that provide a variety of task (Listening, speaking, reading, writing)?. The result show that most of the students are interested in books that provide many examples of conversations, books that present pictures and books that provide various task (listening, speaking, reading, writing). Then, the researcher also gave questionnaires to front office teachers and FO staff. The purpose of the questionnaire was to find out if there were additional language functions that needed to be added in the product. The result is that there is no additional language function from teachers and FO staff. Then, the researcher only use the language function based on the results of the students' checklist.

c. The result of document analysis (textbook and syllabus).

The researcher conducted a need analysis by analyzing the textbook and syllabus curriculum 2013 that was used to teach of XI grade students. The syllabus analysis was done by the researcher to find out the English materials used at SMK N 2 Singaraja for XI grade students in first semester, and also to find out the standard competency as well as learning indicators. From analyzing the syllabus, it was found that there were five topics needed to be developed for $\mathrm{XI}$ grade students in first semester. The communication skill has covered the topics that needed by students of hotel accommodation program to be used in their future work field. Then from the analyzing the textbook, it found that the book still use Bahasa Indonesia, then the book is still lack of conversation, picture, and also monotonous of task.

\section{The Design of English Materials for Front Office Department}

The second finding is related to the development of the learning material. It includes the appearance of the developed book. Then, each unit of discussion is guided by the ESP principle adopted from Hutchinson and Waters (1987) as 
cited in Sri Rahayu and Budasi (2021) consisting of input, content focus, language function, and task. Input aims to motivate students to be interested in learning the material. In the input included short dialogs or pictures that serve the activity of FO staff in the hotel. Second in content focus the students conveyed some information related to the topic. It helped the students to generate meaningful communication. The content focus in the developed material was represented as reading passages. Third is language focus, which discusses language patterns in the form of grammar reviews, vocabulary use complete with how to pronounce it. This language focus is expected to help students more easily understand the grammar, and enrich the vocabulary. And the last is tasks, in this section will present about the various tasks that students must do in order to check their understanding of the material. In addition, providing various problem exercises will help students to master what students expect. The task consists of fourth language skills namely listening, speaking, reading, and writing in each unit related to front office activities.

As stated in the background, in this product, the researcher has compiled the book using two ways, namely printed and e-book. There are some advantages that can be given when students learn to use e-books and textbook. The advantages of use textbook is can be accessed through publisher, printing and libraries to access. Then the advantages of e-book such as students being able to read them wherever and whenever, students just download and save it on their smartphone. In addition, if the number of book pages is large, students can search for a specific section of a book by simply clicking in the search section. This statement can be supported by research conducted by Ebied, Mohammed \& Shimaa Ahmed (2015) entitled "The effect of interactive e-book on students' achievement at Najran University in computer in education course" Researchers stated that e-books can provide many benefits to students, namely e-books are easy to access, organize, easy to return, e-books can be stored and accessed easily so that they can be used anytime and anywhere.

\section{The Quality of the Product English Material for Front Office}

The last finding is regarding to the quality of the developed book. There were two experts who judged the developed material. It was evaluated by experts who are experts in English for Specific Purposes field. The evaluation in form of checklist included a good material adopted from Litz. The data analysed descriptively using the Gregory's formula (2000). Although the material was considered has a very high validity, there were still some revisions needed in order to improve the quality of the product. The result of expert judges checklist can be seen as table below.

Table 2. The Result of Expert Judgment Sheet

\begin{tabular}{|l|l|l|c|l|c|c|}
\hline No. & Dimension & Quality of product & $\begin{array}{c}\text { Relev } \\
\text { ant }\end{array}$ & $\begin{array}{l}\text { Not } \\
\text { Relev } \\
\text { ant }\end{array}$ & & \multicolumn{2}{|c|}{\begin{tabular}{l} 
Score (1-5) \\
\cline { 4 - 7 }
\end{tabular}} & & & $\begin{array}{c}\text { Judge } \\
1\end{array}$ & $\begin{array}{c}\text { Judge } \\
2\end{array}$ \\
\hline 1. & $\begin{array}{l}\text { Layout and } \\
\text { Design }\end{array}$ & $\begin{array}{l}\text { The textbook includes a } \\
\text { detailed overview of the } \\
\text { function, structures and } \\
\text { vocabulary that will be }\end{array}$ & $\sqrt{ }$ & $\sqrt{ }$ & 5 & 5 \\
\hline
\end{tabular}


The Art of Teaching English as a Foreign Language, Vol.2 No.1 2021

DOI: $10.36663 /$ tatefl.v2i1.99

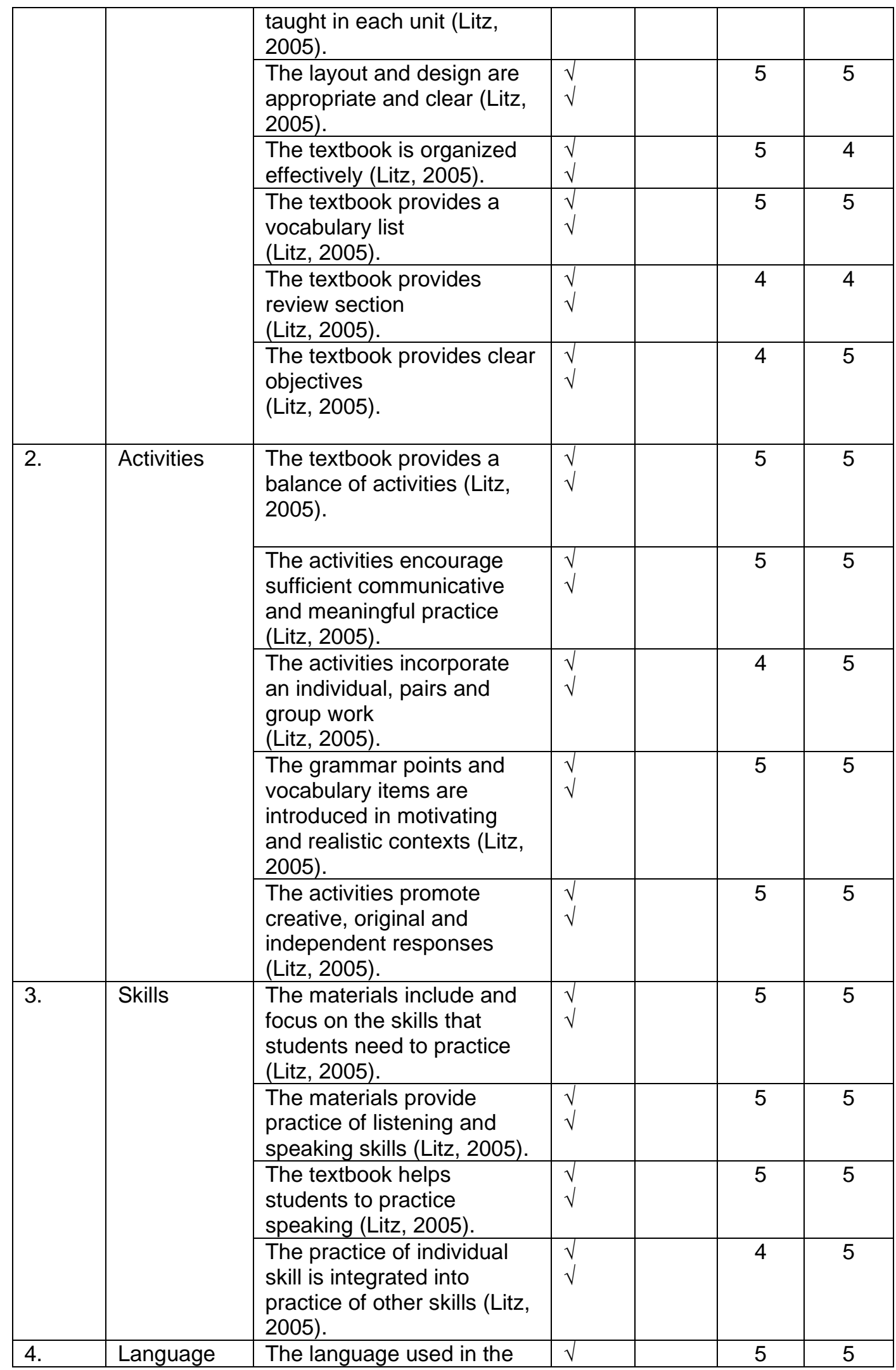




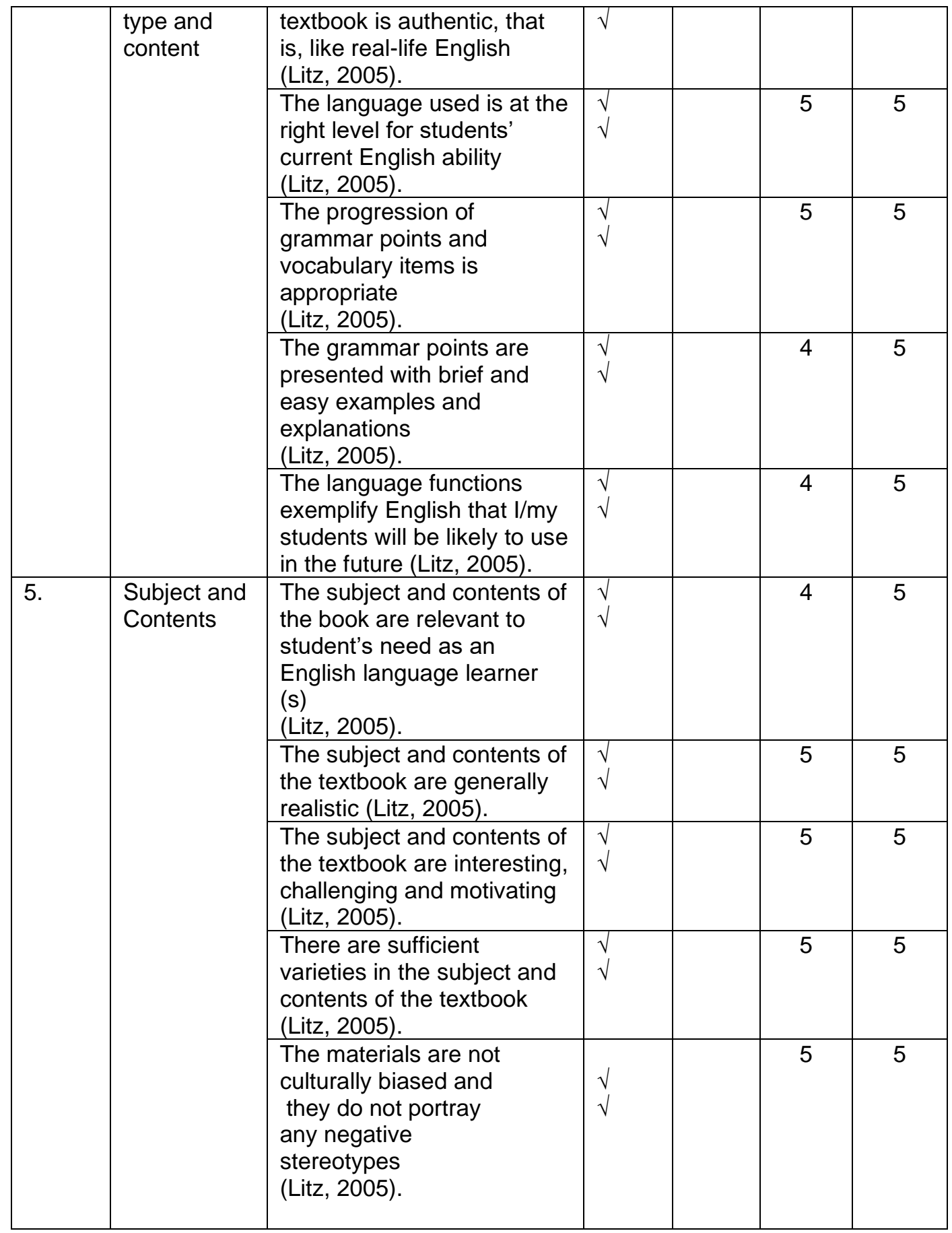

From the results of experts, the contents from two expert judges showed that Gregory's results are 1 which means that the product belongs to a category has a very high validity. In judging the product, the expert give some suggestions and comments to improve the draft of this book. The suggestions can be seen as follow. 
The Art of Teaching English as a Foreign Language, Vol.2 No.1 2021

p-ISSN : 2656-8942, e-ISSN : 2684-8546

DOI: $10.36663 /$ tatefl.v2i1.99

Table 3. Suggestion from the two expert judges of the product

\section{No. Suggestions}

\begin{tabular}{ll}
\hline 1. & Use appropriate grammar (apply in all units) \\
\hline 2. & $\begin{array}{l}\text { Make the layout as attractive as possible and try not to have blank sheets } \\
\text { (apply in all units) }\end{array}$ \\
\hline 3. & $\begin{array}{l}\text { Use more different books as a references when adapted the conversation or } \\
\text { material (apply in all units) }\end{array}$ \\
\hline 4. & $\begin{array}{l}\text { Try to multiply the illustration of images in each unit and use images without } \\
\text { watermarks (apply in all units) }\end{array}$ \\
\hline 5. & The link of images and dialog need to be shortened (apply in all units) \\
\hline 6. & $\begin{array}{l}\text { Instruction on the task needs to be made more specific and clear (apply in all } \\
\text { units) }\end{array}$ \\
\hline 7. & Add the input (apply in all units) \\
\hline 8. & Try to make variety of the task (apply in all units)
\end{tabular}

The advice given by expert judges is used as a reference to revise the draft product and to improve the quality of the product. In order to support this statement, there was previous research named Susanti, et al (2017) conducted the study about "Developing E- Learning English Material Of Front Office Subject For Eleventh Grade Students At SMK N 2 Singaraja that published by Jurnal Pendidikan Bahasa Inggris Undiksha (JPBI). They also adapted formula from Gregory (2000) to evaluate the product. From the evaluation given by the two experts in their study, it was known that the e-learning material is belong to very high quality.

Fatmasari (2018) with a study entitled Esp Analysis On English Materials Design At HICP. This study is to analyze the English materials design of Hospitality Industry College of Purwokerto (HICP) from the aspects of need analysis and principles of ESP's contribution to the creation of materials design of HICP. This study uses descriptive qualitative method and interview, documentation, observation and questionnaire delivered to the students, the ESP teacher, and the stakeholder of HICP to collect the data. To analyze the data, three main steps of data analysis, which are data reduction, display and conclusion, are used. The result shows in this research, that the English materials design of HICP does not meet all of the need analysis result and the principles of ESP. The materials design of HICP only covers the students' learning interest, the goal, the English usage and the setting of frequency, as well as the nature of the learning task and a correct language use.

The second was conducted by Irhani Asmin (2014) entitled A Study On English Terms Used By The Staff Of Front Office Department At The Grand Clarion Hotel Makassar. This study was designed to find out the English terms, the lexical meaning and the contextual meaning of the English special terms used by the staff of Front Office department in the Grand Clarion Hotel Makassar. This study use descriptive qualitative method. The subject of this study is the staff of Front Office department. The instrument used by the 
researcher through participant observation, semi-structured interview and review of the documents. The result of the study showed that the majority of terms used in Front Office department were in English. The researcher found that there 85 (eighty five) English terms were found and 36 (thirty six) of them classified as the English special terms.

The third research was conducted by Damara. A (2014). The method used of this study is Research and Development (R \& D). There are two objectives of this study are; First is to analyze the needs of the hotel reception staff and second is to design appropriate English materials for the hotel reception staff of Vidi Hotel Yogyakarta. There are five procedures were used by the researcher in this study, they are conducting needs analysis, planning (writing the course grid), designing the materials (writing the first draft), expert judgement (evaluating the appropriateness and reviewing the content), and writing the final draft of the materials. The subject of this study included 16 reception staff of Vidi Hotel Yogyakarta. The questionnaires (the needs assessment questionnaire and the expert judgement questionnaire) and interview guideline are used as the instrument in this study. One material expert was involved in the expert judgement process to review and evaluate the materials. The results of the needs assessment questionnaire and the expert judgement were analysed using descriptive statistics and frequencies. The findings of this study show that: (1) the goal of learning English for the reception staff is to guide the receptionist to understand what the guests want, (2) the difficulties of receptionist staff are fluency and vocabulary they used, (3) they prefer oral productive tasks such as short monologues and dialogues and role play in the learning process, (4) the learning materials was evaluate by the expert judgment questionnaire with the value of 4.26 of overall items which include the appropriateness of content, language, presentation and layout. This study also suggests that appropriate learning materials should consist of introduction, lead-in, main activities, evaluation, reflection and summary.

The fourth research was conducted by Ariani (2017). This paper talks about developing an English course book based on task-based approach for Hotel Study Program students of Muhammadiyah University West Sumatera. The development adopted ADDIE model which has five process: Analyze, Design, Develop, Implement and Evaluation. Students' needs were analyzed by interviewing an English lecturer in the institution and a manager of Front Office department in Novotel Hotel Bukittinggi. Observation was also conducted at the department in order to know the language functions and any related forms used by the staffs in performing their tasks. The result of needs analysis was summarized into goals and objectives of the course. These goals and objectives were used to design the book in the form of scope and sequence chart of the unit based on task-based approach. The book was validated by the expert in English for Specific Purposes and two experts in hotel study program. Based on the expert judges, then the result showed that the book was very valid with the average score was 3.70 and recommended to use with few revisions.

The fifth research was conducted by Budasi, et al (2015) at PPLP Dhyana Pura. The title of this study is Developing English Materials for Front Office Course for the Students of Hotel Accommodation of PPLP Dhyana Pura. To develop appropriate English language material for the front office course and examine how relevant English language material is taught to front office course 
students at PPLP Dhyana Pura is the aim of this study. The design of this research is $R \& D$, which is identifying problems and students' needs analysis. The results found are that there are 11 materials that have been developed for the front office course. The last researcher was Rahayu \& Budasi (2021) entitled "Developing English Material For Cruise Line Bartender For Students Of International Bali Institute Of Tourism". This study was adopt the design R \& D proposed by Dick and Carey (2001) which included 5 steps: 1) problem determination (need analysis), 2) design of the model, 3) developing the model, 4) validation by expert and 5) dissemination (trying out the model). This study also applied four aspects by Hutchinson and Waters (2008) in the developed materials (input, content focus, language focus, and task).

\section{CONCLUSION}

Based on findings and discussion, it can be concluded that the learning materials needed by XI grade students in first semester of accommodation hotel program at SMK N 2 Singaraja is a learning materials that cover their English needs as a front office. Then the learning material needed consists of 5 units, namely: (1) Handling incoming calls (2) Handling of telephone calls (3) Reservation process (4) Handling individual reservations (5) Handling group reservations. Each unit of the product included input, content focus, language focus, and tasks. The materials developed were judged by two experts in ESP. The new English materials should be related with the students need with their job in the future.

However, this study was only conducted until the evaluation of the product by the expert judges. At last, the writer hopes this research will be continued by other researchers by implementing this developed materials in the school (SMK N 2 Singaraja) to know whether these materials can help teacher in teaching front office and weather this materials make student's interest and motivate students in studying front office lesson. Then the important thing is whether the activity included in each unit appropriate to help them in fulfilling their duties in their future career or not. The writer hopes this research is useful to the readers.

\section{REFERENCES}

A. Bhakta (2012). Professional Hotel Front Office Management.

Agustina (2014). "ESP; An Approach of English teaching for non English Department students," Beta, vol. 3, no. 2, pp. 100-117.

Astika. G (2015). "The Role of Needs Analysis in English for Specific Purposes," TEFLIN J. - A Publ. Teach. Learn. English, vol. 10, no. 1, p. 31, doi: 10.15639/teflinjournal.v10i1/31-47.

A. I. Asmin (2014)."A Study on English Terms Used by the Staff of Front Office Department at The Grand Clarion Hotel Makasar," Ethical Ling., vol. 1, no. 2, pp. 16-29.

A. Septian Damara (2014). Designing a Course Book for the Reception Staff of Vidi Hotel Yogyakarta.

Budasi, I. G. (2015). English for spesific purposes. Singaraja: Graha Ilmu.

Budasi, I. G \& Lina Kurniawati (2019). English for Hotel . Singaraja, Bali: Mahima Institute Indonesia. 
Badan Pusat Statistik Provinsi Bali. (2020). Perkembangan Pariwisata Provinsi Bali Maret 2020. Bali.Bps.Go.ld, 2019(64), 1-8. https://bali.bps.go.id/pressrelease/2020/05/04/717328/perkembanganpariwisata-provinsi-bali-maret-2020.html

D. Carev (2015). Hotel Sales and the Front Office Operations.

Hutchinson, T., \& Alan, W. (2008). English for specific purposes: A learningcentred approach. Cambridge: Cambridge University Press.

K. E. Ariyanthi, I. N. A. J. Putra, and P. Suarcaya (2020). "English Learning Materials for Restaurant Students at Apollonia Hotel School," J. Educ. Res. Eval., vol. 4, no. 3, p. 252, doi: 10.23887/jere.v4i3.26107.

M. A. E. Mohammed and S. A. A. Rahman (2015). "The effect of interactive EBook on students' achievement at Najran University in computer in education course," J. Educ. Pract., vol. 6, no. 19, pp. 71-83.

Oktaviyanti, Sari., \& Fatmasari, Yuniar. (2018). ESP Analysis on English Materials Design at HICP. Dialektika Journal, 5(2), 149-157.

Rahayu \& Budasi, I. G. (2021). "Developing English Material For Cruise Line Bartender For Students Of International Bali Institute Of." 18(1):66-76.

S. Ariani and T. Faculty (2017), "Developing English Course Book Through T Ask-Based," pp. 377-386, 2017.

Trisyanti, U. (2009). Developing Materials for Esp (English for Specific Purposes) Class. Jurnal Sosial Humaniora, 2(1), 66-77. https://doi.org/10.12962/j24433527.v2i1.666 